\title{
PENINGKATAN DAYA DUKUNG TIANG PANCANG DENGAN PERLAKUAN GEJALA ELEKTROKINETIK
}

\author{
Firmansyah $^{1)}$, R.M. Rustamaji ${ }^{1)}$, Eka Priadi ${ }^{1)}$, Abubakar Alwi ${ }^{1)}$ \\ ${ }^{1)}$ Program studi Magister Teknik Sipil, jurusan Teknik Sipil, FT. UNTAN
}

\begin{abstract}
ABSTRAK
Elektrokinetik adalah suatu gelaja akibat dari medan listrik melalui media porus. Medan listrik dihubungkan dengan ditimbulkan arus listrik searah (DC) secara langsung, yang dapat diaplikasikan untuk meningkatkan daya dukung tanah lunak. Tujuan dari penelitian ini adalah untuk menyelidiki peningkatan tahanan friksi suatu model fondasi tiang pancang ditanah lunak dengan pengaruh perlakuan gejala elektrokinetik. Hasil penelitian menunjukkan bahwa setelah pemancangan dilakukan dengan pengaruh gejala elektrokinetik dengan kuat arus dan waktu tertentu, berturut-turut meningkatkan daya dukung tanah. Rata-rata peningkatan daya dukung tiang tunggal yaitu untuk waktu tunggu 3 hari sebesar 284,679 kg, waktu tunggu 7 hari sebesar 348,443 kg, dan waktu tunggu 15 hari sebesar 380,918 kg.
\end{abstract}

Kata kunci : elektrokinetik, daya dukung, waktu tunggu, kuat arus.

\begin{abstract}
Electrokinetic is a symptom caused by an electric field though a porous medium. The electric field is associated with generated direct electric current $(D C)$ directly, which can be applied to enhance the carrying capacity of soft soil. This research aims to investigate the enhancement of friction resistance and the tip of pile foundation model in soft soil with the effect of electrokinetic symptom treatment. The result showed that after the pilling was carried out with the certain current and time, soft soil carrying capacity will increase. The average enhancement of single pole carrying single pole carrying capacity for 3 days waiting time is 284,679 kg, 7 days waiting time is 348,443 $\mathrm{kg}$ and 15 days waiting time is $380,918 \mathrm{~kg}$.
\end{abstract}

The key word : Electrokinetic, Carrying Capacity, waiting time, Current

\section{PENDAHULUAN}

Suatu sistem fondasi yang terpasang ditanah lunak dengan kondisi floated fondation pada umumnya menghadapi permasalahan geoteknis yang berkaitan dengan rendahnya daya dukung tanah dan terjadi penurunan, maka perbaikan atau stabilisasi tanah menjadi solusi alternatif. Kenyataan tersebut mendorong berkembang pesatnya teknik-teknik perbaikan tanah.

Penelitian ini dilakukan dengan menggunakan model tiang skala kecil yang dipancangkan langsung di lapangan. Dari penelitian ini diharapkan dapat diketahuipengaruh kuat arus dan waktu terhadap peningkatan tahanan dari tiang baja di tanah lempung setelah dilakukan proses elektrokinetik sedemikian hingga dapat meningkatkan kapasitas daya dukungnya

Manfaat dan tujuan yang ingin dicapai dari penelian ini adalah untuk menganalisa daya dukung tiang pancang sebelum dan sesudah proses

Firmansyah

Imannando67@gmail.com elektrokinetik, guna mengetahui seberapa besar pengaruh yang ditimbulkan dari fenomena elektroosmosis terhadap daya dukung tiang pancang. Penelitian ini dilakukan dengan menggunakan model tiang skala kecil yang dipancangkan langsung dilapangan tanpa perlakuan dan dengan perlakuan elektrokinetik, dan setelah itu akan dibandingkan kekuatannya.

\section{TEORI DASAR}

Menurut catatan historis dari penyelidikan elektroosmosis, Reuss (Rusia, 1808) tercatat sebagai ilmuan pertama yang melaksanakan percobaan elektrokinetik di dalam tanah.Ia mencatat bahwa air yang mengalir di dalam tanah akibat pengaruh suatu medan listrik DC. Gejala ini dikenal sebagai gejala elektrokinetik pada tanah (Azzam dan Oey, 2001).Dua elektroda ditanamkan di dalam tanah kemudian dialiri kuat arus searah (direct current) yang dilewatkan melalui kedua elektroda tersebut (katoda dan anoda).Arus searah ini melewati tanah yang menghasilkan perpindahan ionion. Pada saat kedua kutub anoda dan katoda ditanam 
dan diberi beda potensial, maka akan terjadi proses elektrolisis menurut reaksi sebagai berikut

Anoda : $\quad 2 \mathrm{H}_{2} \mathrm{O}-4 \mathrm{e}^{-} \rightarrow \mathrm{O}_{2}+4 \mathrm{H}^{+}$

Katoda : $\quad 2 \mathrm{H}_{2} \mathrm{O}+2 \mathrm{e}^{-} \rightarrow \mathrm{H}_{2}+2 \mathrm{OH}^{-}$

Dari proses diatas, dapat dilihat bahwa saat diberi arus listrik searah (DC), air pada anoda akan berubah menjadi gas oksigen dan kation $\left(\mathrm{H}^{+}\right)$. Gas oksigen ini akan bersenyawa dengan logam kutub positif dan menyebabkan karat pada anoda. Sedangkan, kation akan bergerak menuju anoda sambil membawa sejumlah molekul air.

Saat kation-kation tersebut mencapai katoda, air yang terkandung dalam kation tersebut akan dilepaskan dan menekan air keluar ke permukaan. Hal ini menyebabkan munculnya genangan air di sekitar katoda. Melalui penerapan medan listrik di dalam media tanah yang porus dihasilkan beberapa gejala-gejala elektrokinetis yang dapat berlaku di dalam tanah.

$$
\text { Gejala-gejala tersebut berupa gejala }
$$
elektroosmosis, elektromigrasi, elektroforesis dan streaming potential. Melalui gejala elektrokinetis, utamanya akan menimbulkan pergerakan silang ion-ion di dalam tanah sedemikian hingga apabila ion-ion tersebut adalah berupa cementing agents maka reaksi precipitation dapat terjadi dan menimbulkan pengaruh sementasi, koagulasi dan pada akhirnya meningkatkan kekuatan tanah.

\section{PRINSIP ELEKTROKINETIK}

Elektrokinetik merupakan suatu teknik yang belum banyak dipraktekkan pada dunia konstruksi, digunakan untuk menstabilkan lahan. Proses yang sangat berperan penting dalam teknik ini adalah gejala elektrokinetik, yang terdiri dari elektroosmosis, elektroporesis, elektromigrasi, dan steaming potensial.

Elektroosmosisdapat didefinisikan sebagai gejala yaitu ketika sebuah medan listrik diberikan dalam suatu media tanah akan menyebabkan pergerakan larutan dan permukaan partikel yang aktif ikut bergerak, pergerakan lapisan yang tersebar sebenarnya ialah ion-ion bermuatan yang pindah dan bergerak di bawah medan listrik. Elektroforesis dapat diidentifikasi sebagai perpindahan koloid-koloid yang bermuatan dalam suatu material yang berupa pasta di bawah perbedaan potensial listrik.Elektromigrasi ialah pergerakan ion-ion bermuatan ke arah elektroda yang memiliki muatan yang berlawanan.Elektromigrasi dapat terjadi di dalam sebuah sistem medium yang porus dengan konsentrasi cairan yang mengandung elektrolit.

\section{METODOLOGI}

Penelitian yang dilakukan secara umum merupakan penelitian lapangan yang menggunakan data loading test tiang tunggal, dimana membandingkan hasil uji daya dukung Ultimate tiang tunggal sebelum dan sesudah proses elektrokinetik selama waktu tunggu yang telah ditentukan. Sedangkan hasil interpretasi data loading test menggunakan tiga metode yaitu : Metode Elastis Plastis, Metode Mazurkiewich, dan Metode Chin, sehingga akan didapat daya dukung rata-rata tiang fondasi.

\section{BAHAN DAN PERLATAN}

Adapun bahan atau sampel yang digunakan dalam pelaksanaan penelitian ini adalah :

- Model tiang pancang tunggal digunakan tiang baja pipa diameter $4 \mathrm{~cm}$ dengan panjang $430 \mathrm{~cm}$. Berfungsi sebagai anoda pada saat diberi perlakuan elektrokinetik.

- Baja tulangan diameter $10 \mathrm{~mm}$ dengan panjang 430 $\mathrm{cm}$. Berfungsi sebagai katodapada saat diberi perlakuan elektrokinetik.

Formasi keduanya pada lokasi tempat tiang pancang di tanah kedalaman ditujukkan pada gambar 1, 2 dan gambar 3 .

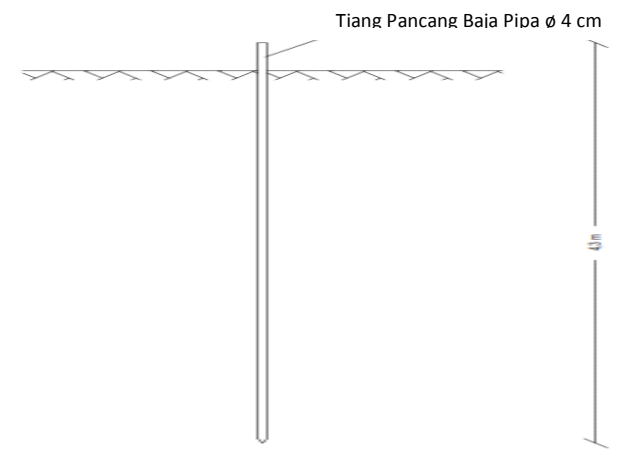

Gambar 1. Tiang tunggal tanpa perlakuan elektrokinetik

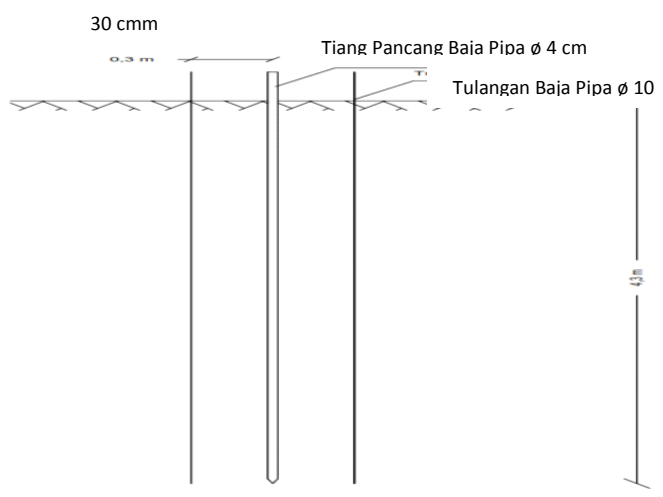

Gambar 2. Tiang tunggal dengan perlakuan elektrokinetik Katoda (-) Katoda ( - )

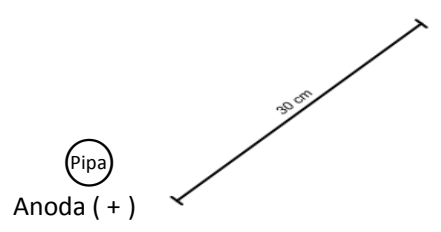

Katoda ( - )

Katoda ( - )

Gambar 3. Jarak antar elektroda 


\section{PROSEDUR PENELITIAN}

\section{Tiang tanpa perlakuan elektrokinetik}

1. Langkah Pekerjaan

Adapun langkah-langkah pekerjaan yang dilakukan:

a. Pembersihan lokasi penelitian.

b. Pemancangan tiang tunggal baja pipa sedalam \pm 4 m untuk waktu tunggu 3,7 , dan 15 hari masingmasing sebanyak 3 sampel.

\section{Tiang dengan perlakuan elektrokinetik}

\section{Langkah Pekerjaan}

Adapun langkah-langkah pekerjaan yang dilakukan:

a. Pembersihan lokasi penelitian.

b. Pemancangan tiang tunggal baja pipa sedalam \pm 4 $\mathrm{m}$.

c. Pemancangan baja tulangan sedalam $\pm 4 \mathrm{~m}$ sejarak $30 \mathrm{~cm}$ dari tiang baja pipa pada 4 arah mata angin yang tegak lurus.

d. Instalasi alat untuk perlakuan elektrokinetik yang dilakukan dengan mengalirkan listrik searah selama 7 hari pada tiang-tiang yang baru dipancang dengan variabel kuat arus $20 \mathrm{~mA}, 40 \mathrm{~mA}, 80 \mathrm{~mA}, 160 \mathrm{~mA}$, dan $320 \mathrm{~mA}$. Khusus tntuk tiang tunggal dengan perlakuan elektrokinetik yang dialiri arus $20 \mathrm{~mA}$, akan diuji dengan variabel waktu pengaliran listrik yaitu 3,7 , dan 15 hari.

\section{Penetapan Beban Rencana}

Pengambilan beban percobaan menggunakan hasil dari tes sondir dengan menggunakan persamaan Metode Schmertmann - Nottingham (1975) dan Uji Laboratorium.

\section{Uji Pembebanan Tiang (Loading Test)}

Uji pembebanan tiang dilakukan dengan tujuan untuk mengetahui seberapa besar daya dukung batas tiang. Daya dukung tiang rencana dihitung berdasarkan nilai daya dukung yang didapat dari data sekunder sondir.

\section{Pola Pembebanan}

Untuk pelaksanaan uji pembebanan dilakukan dengan cara pembebanan tidak langsung, dimana prinsip kerjanya adalah tiang uji ditekan dengan menggunakan jackhydraulic yang diletakkan diatas tiang uji. Bagian bawah ditumpukkan pada suatu perkuatan menggunakan angkur.

\section{Peralatan Pembebanan}

Adapun peralatan yang digunakan pada uji pembebanan ini antara lain:

a. Tiang tunggal baja pipa dengan panjang kedalam tanah $\pm 4 \mathrm{~m}$.

b. Arloji ukur (dial gauge) 2 buah.

c. Jackhydraulic dengan kapasitas 10 ton dengan ketelitian $50 \mathrm{~kg}$.

d. Stopwatch untuk mengukur waktu pembebanan.

e. Meja beban dari bahan baja.

f. Beban kontra dari kubus beton.

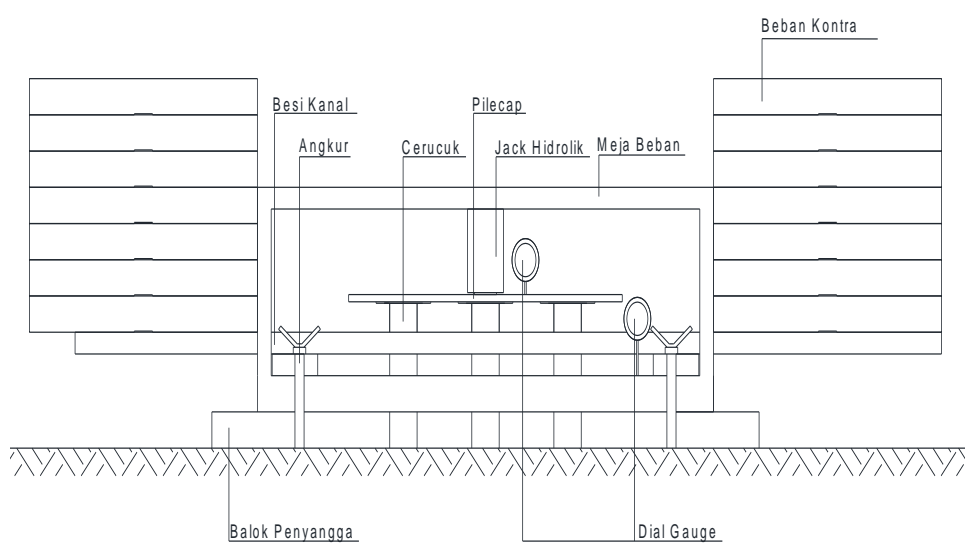

Gambar 4. Meja loading dan perlengkapannya

Secara garis besar prosedur penelitian dapat digambarkan dalam bagan dibawah ini.

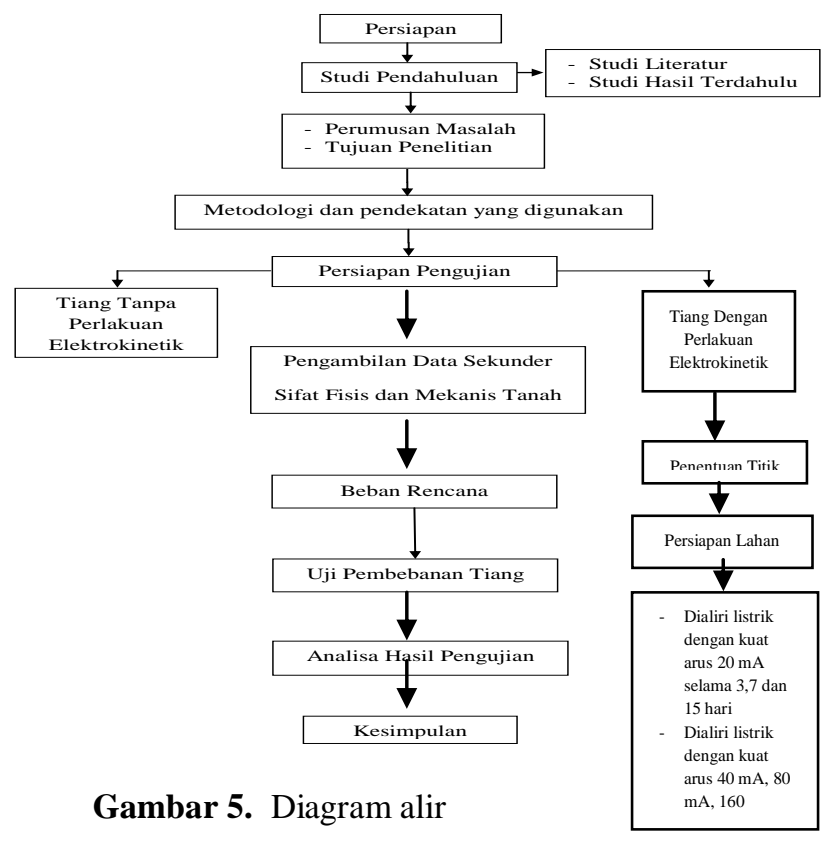

\section{HASIL DAN ANALISA DATA}

\section{Pembebanan Daya Dukung Tiang Tunggal Tanpa Perlakuan Elektrokinetik}

Setelah dilakukan uji pembebanan dengan metode Quick Maintained Load Test didapatkan data beban dan jarak penurunan yang terjadi untuk masing-masing waktu tunggu 3, 7, dan 15 hari untuk tiang tunggal tanpa perlakuan elektrokinetik

Dari hasil uji pembebanan dapat dilakukan interpretasi untuk menentukan besarnya daya dukung ultimate tiang tunggal.

Rekapitulasi hasil interpretasi daya dukung Ultimate tiang tunggal tanpa perlakuan elektrokinetik untuk masing-masing waktu tunggu 3, 7, dan 15 hari dapat dilihat pada Tabel 1. sebagai berikut: 


\begin{tabular}{|c|c|c|c|c|c|}
\hline \multirow{3}{*}{ Waktw The (hri) } & \multirow{3}{*}{ Sanpel } & \multicolumn{4}{|c|}{ 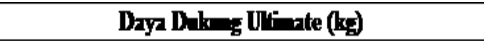 } \\
\hline & & \multicolumn{4}{|c|}{ Metade } \\
\hline & & Dhstis-Fhstis & Mandievin & (5) & Ratn-Rat \\
\hline \multirow{4}{*}{3} & Sampe 1 & 285 & 271 & 292,398 & \multirow{4}{*}{284,679} \\
\hline & Sampe 2 & 280 & 278 & 295,928 & \\
\hline & Sampe13 & 286 & 282 & 291,783 & \\
\hline & Ratn-rat & 283,657 & $277, \mathbf{m}$ & 293,370 & \\
\hline \multirow{4}{*}{7} & Sampe 1 & 347 & 350 & 314,228 & \multirow{4}{*}{348,413} \\
\hline & Sampe 2 & 365 & 359 & 333,067 & \\
\hline & Sampe 3 & 345 & 349 & 373,692 & \\
\hline & Ratanta & 352,333 & 352,657 & 340,329 & \\
\hline \multirow{4}{*}{15} & Sampe 1 1 & 367 & 375 & 394,011 & \multirow{4}{*}{ 384,918 } \\
\hline & Sampe 2 & 370 & 373 & 428,229 & \\
\hline & Sampe13 & 365 & 384 & 372,024 & \\
\hline & Ratarnta & 367,333 & 377,333 & 398,088 & \\
\hline
\end{tabular}

Tabel 1. Daya dukung tiang tunggal tanpa perlakuan elektronetik

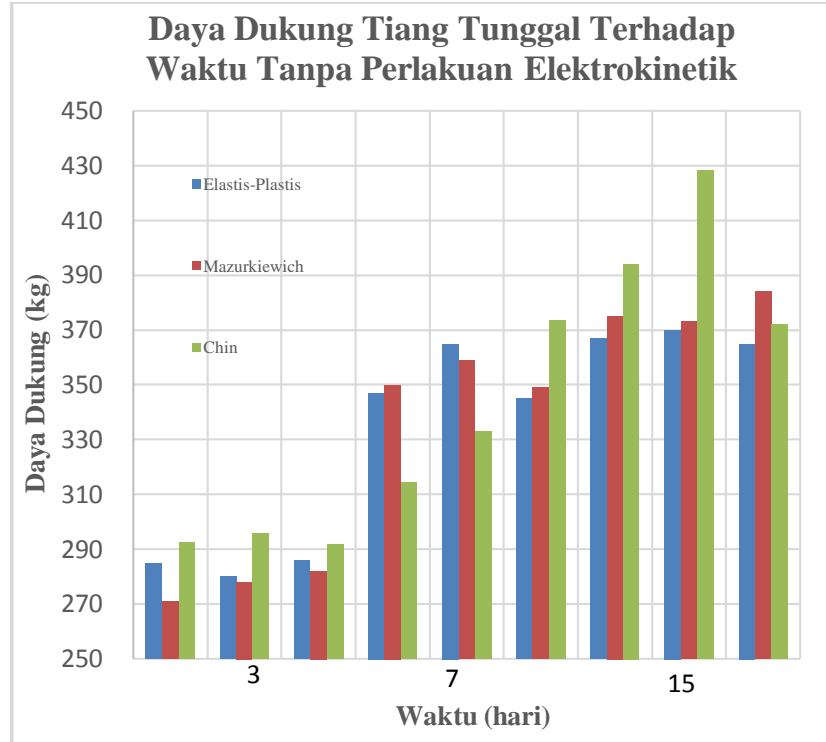

Grafik 1. Rekapitulasi interpretasi daya dukung ultimate tiang tunggal Tanpa perlakuan elektrokinetik

Berdasarkan data Tabel 1 diatas, dapat dilihat bahwa terjadi peningkatan daya dukung tiang tunggal tanpa perlakuan elektrokinetik untuk waktu tunggu yang lebih lama. Adapun rata-rata peningkatan daya dukung tiang tunggal yaitu untuk waktu tunggu 3 hari sebesar $284,679 \mathrm{~kg}$, waktu tunggu 7 hari sebesar $348,443 \mathrm{~kg}$, dan wantu tunggu 15 hari sebesar 380,918 kg. Peningkatan daya dukung ini dipengaruhi oleh menurunnya tekanan air pori secara alami. Pada awal pemancangan tekanan air pori akan meningkat dan setelah dibiarkan pada jangka waktu tertentu tekanan air pori akan secara perlahan turun secara alami sehingga meningkatkan tegangan efektif tanah.

Apabila dibandingkan dengan daya dukung rencana awal dari data sekunder uji laboratorium dan uji sondir, maka daya dukung yang paling mendekati adalah daya dukung hasil uji sondir dengan daya dukung hasil loading test dengan waktu tunggu 7 hari.Besarnya daya dukung untuk setiap metode secara lengkap dapat dilihat pada Grafik 2.

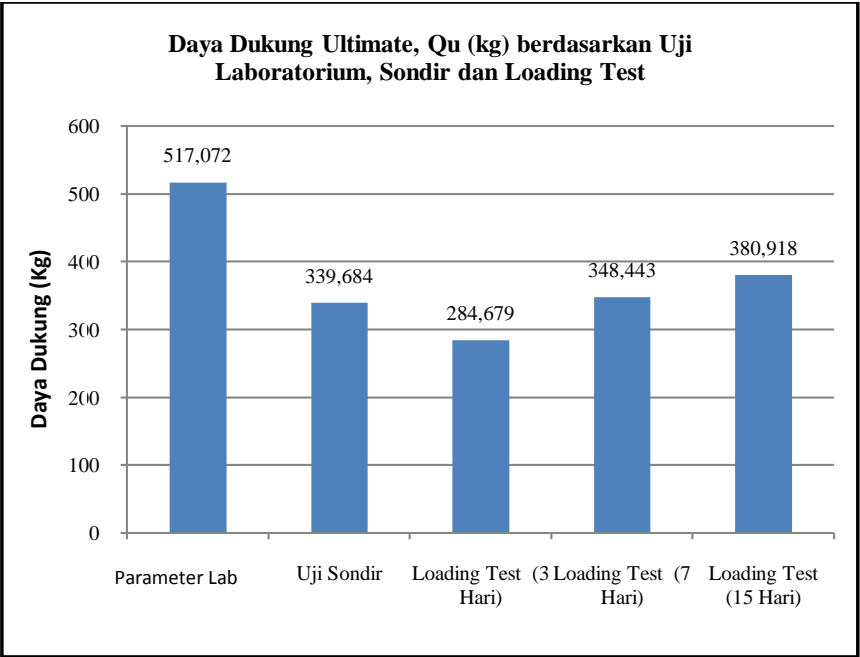

Grafik 2. Grafik daya dukung data awal dan hasil loading test

\section{Pembebanan Daya Dukung Tiang Tunggal Dengan} Perlakuan Elektrokinetik

Setelah dilakukan uji pembebanan dengan metode Quick Maintained Load Testdidapatkan data beban dan jarak penurunan yang terjadi untuk masing-masing waktu tunggu tiang tunggal dengan perlakuan elektrokinetik.

Dari hasil uji pembebanan dapat dilakukan interpretasi untuk menentukan besarnya daya dukung tiang tunggal.

Rekapitulasi hasil interpretasi daya dukung ultimate tiang tunggal dengan perlakuan elektrokinetik untuk masing-masing waktu tunggu 3, 7, dan 15 hari dapat dilihat pada Tabel 2. sebagai berikut:

\begin{tabular}{|c|c|c|c|c|c|c|}
\hline \multirow{3}{*}{ Whath TEgs (min) } & \multirow{3}{*}{$\operatorname{Ars}(A d)$} & \multirow{3}{*}{ Sarpel } & \multicolumn{4}{|c|}{ 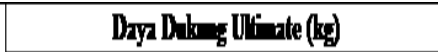 } \\
\hline & & & \multicolumn{4}{|c|}{ Metale } \\
\hline & & & Dhastis-Phastis & Madievid & di & Rath-nth \\
\hline \multirow{4}{*}{3} & \multirow{4}{*}{20} & 1 & 308 & 311 & 336,836 & \multirow{4}{*}{316,151} \\
\hline & & 2 & 293 & 300 & 333,333 & \\
\hline & & 3 & 303 & 306 & 356,888 & \\
\hline & & Ratr-nth & 301,333 & $3 \%, 69$ & 342,353 & \\
\hline \multirow{4}{*}{7} & \multirow{4}{*}{20} & 1 & 420 & 425 & 447,547 & \multirow{4}{*}{122,29} \\
\hline & & 2 & 417 & 424 & 459,897 & \\
\hline & & 3 & 400 & 403 & 401,994 & \\
\hline & & Rath-nth & 12,333 & 417333 & (36,47) & \\
\hline \multirow{4}{*}{15} & \multirow{4}{*}{20} & 1 & 448 & 437 & 524,439 & \multirow{4}{*}{176,851} \\
\hline & & 2 & 445 & 451 & 521,485 & \\
\hline & & 3 & 460 & 459 & 545,732 & \\
\hline & & Ratr-nt & 151,w & $49, m$ & 530,552 & \\
\hline
\end{tabular}

Tabel 2. Rekapitulasi interpretasi daya dukung Ultimate tiang tunggal dengan perlakuan elektrokinetik 


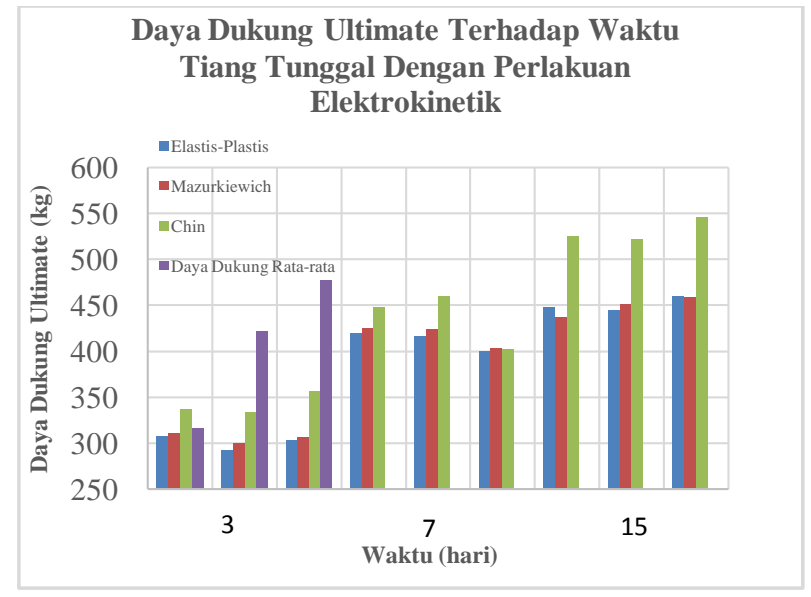

Grafik 3. Rekapitulasi interpretasi daya dukung Ultimate tiang tunggal dengan perlakuan elektrokinetik

Berdasarkan Grafik 3 diatas, dapat dilihat bahwa terjadi peningkatan daya dukung tiang tunggal dengan perlakuan elektrokinetik dengan arus $20 \mathrm{~mA}$ untuk waktu tunggu yang lebih lama. Adapun rata-rata peningkatan daya dukung tiang tunggal yaitu untuk waktu tunggu 3 hari sebesar 316,451 kg, waktu tunggu 7 hari sebesar $422,049 \mathrm{~kg}$, dan waktu tunggu 15 hari sebesar 476,851 kg. Peningkatan daya dukung ini akibat meningkatnya tegangan efektif tanah karena gejalagejala elektrokinetik berupa gejala elektroosmosis, elektromigrasi, elektroforesis, dan streaming potensial selama proses perlakuan elektrokinetik. Melalui gejala elektrokinetik ini terjadi pergerakan silang ion-ion yang berupa cementing agent sehingga terjadi reaksi precipitation dan menimbulkan pengaruh sementasi, koagulasi, dan akhirnya meningkatkan tegangan efektif tanah.

\section{Kuat Geser Tanah Undrained}

Kuat geser tanah merupakan salah satu parameter daya dukung tanah. Untuk tiang tunggal dengan perlakuan elektrokinetik dengan arus $20 \mathrm{~mA}$ dilakukan pengujian vane shear test tanah di lapangan sebelum dan sesudah perlakuan elektrokinetik. Adapun hasil pengujian vane shear test tanah di lapangan disajikan pada Tabel 3.

\begin{tabular}{|c|c|c|c|}
\hline Sampel Tanah & $\begin{array}{c}\text { Torsi } \\
\text { Maksimum }\end{array}$ & $\begin{array}{c}\text { Undrained Shear } \\
\text { Strenght (Su) }\left(\mathbf{k g} / \mathbf{c m}^{\mathbf{2}}\right)\end{array}$ & $\begin{array}{c}\text { Undrained Shear } \\
\text { Strenght (Su) (kPa) }\end{array}$ \\
\hline Tanpa Perlakuan & 4,3 & 0,147 & 14,665 \\
\hline Anoda & 5,6 & 0,191 & 19,099 \\
\hline Katoda & 3,3 & 0,113 & 11,255 \\
\hline
\end{tabular}

Tabel 3. Hasil pengujian vane shear test di anoda pada tiang tunggal untuk waktu tunggu 7 hari dengan arus $20 \mathrm{~mA}$

Dari Tabel 3. dapat dilihat bahwa lamanya waktu tunggu tiang tunggal dengan perlakuan elektrokinetik dengan arus $20 \mathrm{~mA}$ sangat berpengaruh pada nilai kuat geser tanah di anoda, hal ini disebabkan karena prosesproses yang terjadi selama proses elektrokinetik. Pada akhir pengujian, kuat geser tanah di anoda lebih besar dari pada kuat geser tanah sebelum perlakuan elektrokinetik.Hal ini menunjukkan bahwa kuat geser tanah sebagai salah satu parameter daya dukung tanah memberikan pengaruh pada meningkatnya daya dukung tiang tunggal berdasarkan lamanya waktu tunggu tiang tunggal yang diberi perlakuan elektrokinetik.

\section{Penampakan Visual Tiang Tunggal Hasil Pengujian Elektrokinetik}

Setelah tiang tunggal dilakukan uji pembebanan, maka tiang-tiang tunggal tersebut kemudian dicabut.Ketika pencabutan tiang-tiang tunggal dilakukan pengamatan kondisi tanah yang melekatpada tiang secara visual.Dapat dilihat pada Gambar 5 tanah pada sekitaran tiang tunggal (anoda) setelah perlakuan elektrokinetik mengalami penggumpalan ketika dicabut.Penggumpalan ini diakibatkan oleh sementasi dan koagulasi pada tanah akibat fenomena elektrokinetik.

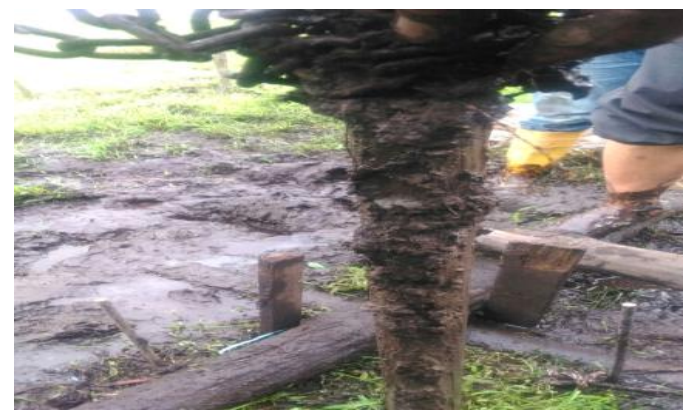

Gambar 6. Penampakan visual tanah di sekitar tiang tunggal (anoda) setelah perlakuan elektrokinetik

Selain itu dapat dilihat pula pada Gambar 6.bahwa baja tulangan yang berlaku sebagai katoda tampak memiliki kondisi lebih basah setelah dilakukan perlakuan elektrokinetik. Hal ini disebabkan oleh perpindahan air dari anoda menuju katoda, sehingga kadar air disekitar katoda lebih tinggi.

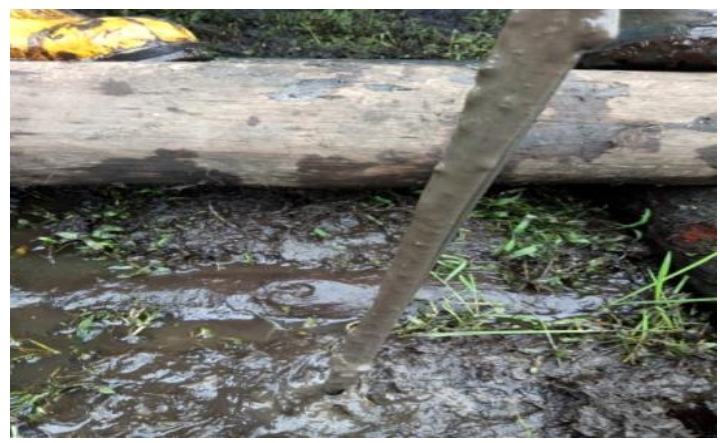

Gambar 7. Penampakan visual tanah di sekitar baja tulangan (katoda) setelah perlakuan elektrokinetik

Dari proses kimia yang dibahas di atas, dapat dilihat bahwa saat diberi arus listrik searah (DC), air pada anoda akan berubah menjadi gas oksigen dan kation $\left(\mathrm{H}^{+}\right)$. Gas oksigen ini akan bersenyawa dengan logam kutub positif dan menyebabkan karat pada anoda. 
Hal ini dibuktikan dengan penampakan visual tiang baja (anoda) yang berkarat setelah perlakuan elektrokinetik.

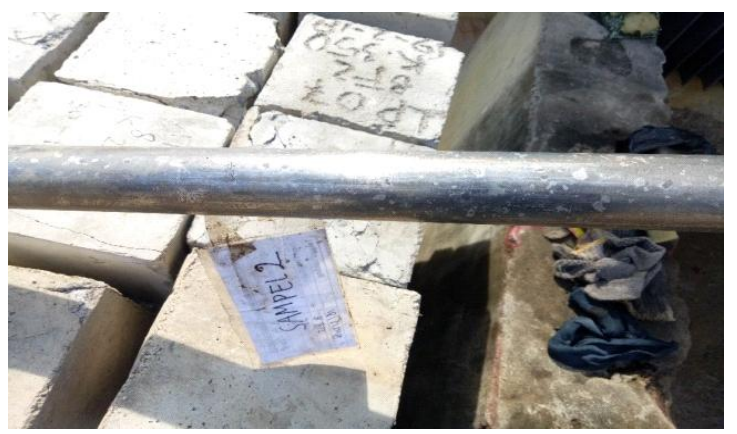

Gambar 8. Penampakan visual tiang tunggal (anoda) sebelum perlakuan elektrokinetik

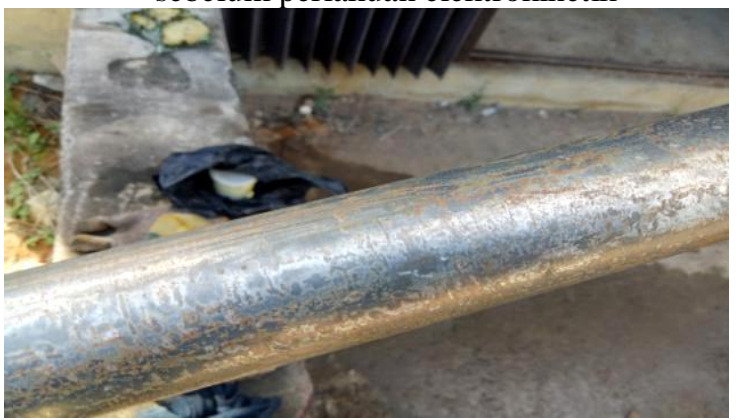

Gambar 9. Penampakan visual tiang tunggal (anoda) setelah perlakuan elektrokinetik

\section{Kesimpulan}

Berdasarkan analisa data hasil pengujian, pengolahan data yang telah dilakukan, maka dapat diambil kesimpulan sebagai berikut :

- Berdasarkan data sekunder tes laboratorium dan tes sondir pada tanah di lokasi penelitian, didapatkan hasil klasifikasi tanah sebagai berikut:

- Klasifikasi tanah menurut USCS menunjukkan bahwa tanah termasuk golongan $\mathrm{OH}$, dimana $\mathrm{OH}$ adalah lempung organik dengan plastisitas sedang sampai tinggi.

- Klasifikasi tanah menurut AASHTO menunjukkan bahwa tanah termasuk golongan A-7-5, dimana golongan A-7-5 adalah tanah berlempung.

- Klasifikasi tanah menurut USDA menunjukkan bahwa tanah termasuk campuran tanah liat dan lempung berlanau.

- Konsistensi tanah pada lokasi pengujian merupakan tanah sangat lunak (verysoft soil).

- Dari hasil loading test, daya dukung tiang tunggal $\left(Q_{u}\right)$ tanpa perlakuan memiliki nilai yang mendekati daya dukung $\left(\mathrm{Q}_{\mathrm{u}}\right)$ awal dari data sondir pada waktu tunggu 7 hari.

- Berdasarkan interpretasi daya dukung tiang tunggal dari hasil loading test menunjukkan adanya peningkatan daya dukung tiang tunggal berdasarkan lamanya waktu tunggu tiang tunggal 3,7 , dan 15 hari. Untuk tiang tunggal tanpa perlakuan elektrokinetik, rata-rata peningkatan daya dukungnya yaitu sebesar $284,679 \mathrm{~kg}, 348,443 \mathrm{~kg}$, dan 380,918 kg. Sedangkan untuk tiang tunggal dengan perlakuan elektrokinetik, rata-rata peningkatan daya dukungnya yaitu sebesar $316,451 \mathrm{~kg}, 422,049 \mathrm{~kg}$, dan 476,851 $\mathrm{kg}$.

- Daya dukung tiang tunggal dengan perlakuan elektrokinetik lebih besar daripada daya dukung tiang tunggal tanpa perlakuan elektrokinetik. Adapun persentase peningkatan daya dukung setelah perlakuan elektrokinetik untuk waktu tunggu 3, 7, dan 15 hari yaitu sebesar $11,161 \%, 21,124 \%$, dan $25,185 \%$.

- Setelah perlakuan elektrokinetik, daya dukung $\left(\mathrm{Q}_{\mathrm{u}}\right)$ tiang tunggal dibandingkan dengan tiang tanpa perlakuan pada waktu tunggu yang sama ( 7 hari) untuk pemberian kuat arus $20 \mathrm{~mA}, 40 \mathrm{~mA}, 80 \mathrm{~mA}$, $160 \mathrm{~mA}$, dan $320 \mathrm{~mA}$ masing-masing mengalami kenaikan sebesar $21,1 \% ; 26,0 \% ; 33,7 \% ; 38,5 \%$; dan $45,2 \%$.

- Semakin besar kuat arus yang diberikan, semakin besar pula beda potensialnya, menunjukkan semakin cepat proses elektroosmotik yang terjadi.

- Peningkatan daya dukung tiang tunggal tanpa perlakuan elektrokinetik dikarenakan menurunnya tekanan air pori secara alami akibat pemancangan tiang tunggal.

- Peningkatan daya dukung tiang tunggal dengan perlakuan elektrokinetik dikarenakan gejala-gejala elektrokinetik berupa gejala elektroosmosis, elektromigrasi, elektroforesis, dan streaming potensial selama proses perlakuan elektrokinetik yang menimbulkan pengaruh sementasi, koagulasi, dan akhirnya meningkatkan tegangan efektif tanah.

- Dilihat dari hubungan antara tegangan (volt) dan waktu menunjukkan bahwa semakin lama waktu perlakuan elektrokinetik maka lamanya proses elektroosmosis yang terjadi akan semakin lama sehingga air pori yang dipindahkan semakin banyak dan daya dukungnya dapat semakin meningkat.

- Hasil pengujian sampel tanah sebelum dan sesudah perlakuan elektrokinetik menunjukkan bahwa parameter-parameter daya dukung tanah mengalami perubahan, antara lain:

- Untuk hasil pengujian pH tanah, pH tanah pada daerah anoda lebih kecil daripada tanah di daerah katoda dan tanah sebelum perlakuan elektrokinetik.

- Untuk hasil pengujian permeabilitas tanah, permeabilitas tanah pada daerah anoda lebih kecil daripada tanah sebelum perlakuan elektrokinetik.

- Untuk hasil pengujian kuat geser tanah, kuat geser tanah tanah pada daerah anoda lebih besar daripada tanah sebelum perlakuan elektrokinetik.

- Secara visual dapat dilihat bahwa tanah pada sekitaran tiang tunggal (anoda) setelah perlakuan elektrokinetik mengalami penggumpalan ketika dicabut. Penggumpalan ini diakibatkan oleh sementasi dan koagulasi pada tanah akibat fenomena elektrokinetik. Dapat dilihat pula bahwa baja tulangan yang berlaku sebagai katoda tampak memiliki kondisi lebih basah setelah dilakukan 
perlakuan elektrokinetik. Hal ini disebabkan oleh perpindahan air dari anoda menuju katoda, sehingga kadar air disekitar katoda lebih tinggi. Serta akibat proses elektrolisis yang terjadi dapat dilihat pada tiang baja (anoda) berkarat setelah perlakuan elektrokinetik.

- Metode elektrokinetik yang dilakukan dengan ukuran fondasi tiang pancang yang kecil di lapangan ini dapat diaplikasikan di lapangan dengan ukuran fondasi tiang pancang yang lebih besar sebagai alternatif untuk solusi metode perbaikan tanah.

\section{Daftar Pustaka}

Agustina. 2013. Analisa Kombinasi Pre-loading Mekanis dan Elektrokinetis Terhadap Pemampatan Tanah Lunak Pontianak. Skripsi. Fakultas Teknik Universitas Tanjungpura.

Azami, Fikri Irfanil. 2017. Kajian Efisiensi Kelompok Tiang Dengan Konfigurasi 3x3. Skripsi. Fakultas Teknik Universitas Tanjungpura.

Azzam dan Oey, 2001.The Utilization of Electrokinetics in Geotechnical and Environmental Engineering

Das, Braja M. 1998. Mekanika Tanah (Prinsip-prinsip Rekayasa geoteknis) Jilid 1. Jakarta: Erlangga.

Das, Braja M. 1998. Mekanika Tanah (Prinsip-prinsip Rekayasa geoteknis) Jilid 2. Jakarta: Erlangga.

Dika. 2009. Elektrorestorasi Tanah Lunak Pontianak yang Terkontaminasi Logam Berat. Skripsi. Fakultas Teknik Universitas Tanjungpura.

Hardiyatmo, Hary Christandy. 2002. Mekanika Tanah 1. Yogyakarta : Gadjah Mada University Press.

Hausmann, Manfred R. 1990. Engineering Principles of Groung Modification. Singapore: McGraw-Hill Book Co.

Lim, Aswin. 2014. Evaluasi Formula Penentuan Daya Dukung Aksial Tiang Pancang Tunggal Menggunakan Data CPT Berdasarkan Metode Langsung (Direct Method).Lembaga Penelitian dan Pengabdian Pada Masyarakat Universitas Katolik Parahyangan.

Rahardjo, Paulus P. 2013. Manual Pondasi Tiang Edisi 4.Bandung : Universitas Katolik Parahyangan.

Rustamaji, R.M. 2007.Ground Improvement using Electro-Chemical Injection, Mitteilungen zur Ingeniurgeologie und Hydrogeologie, Lehrstuhl fur Ingeniurgeologie und Hydrogeologie RWTH-Aachen, Druck und verlag Maintz. Aanchen - Germany.

Sardjono, H.S. 1984. Pondasi Tiang Pancang Jilid 1. Surabaya : Sinar Wijaya.

Sepriawan, Muhar. 2012. Studi Pemampatan Tanah Lunak Pontianak dengan pengaruh Gejala Elektroosmosis. Pontianak : Fakultas Teknik Universitas Tanjungpura.

Tim Pusat Litbang Prasarana Transportasi Bandung. 2002. Panduan Geoteknik 1 Proses Pembentukan dan Sifat-sifat Dasar Tanah Lunak Edisi Pertama. Lembaga : Bandung.
Wirdayanti, Ni Nengah. 2010. Studi Eksperimental Elektromediasi Kontaminasi Logam Berat Pada Tanah. Tesis. Fakultas Teknik Universitas Tanjungpura.

Yunata, Vivi Aurora. 2009. Elektrorestorasi Tanah Lempung Capkala yang Terkontaminasi oleh Logam Berat.Skripsi. Fakultas Teknik Universitas Tanjungpura.

Yeung, 1994.Mekanika Tanah 